\title{
ONTOGENETIC EVENTS IN ANDROGENESIS OF BRAZILIAN BARLEY GENOTYPES
}

\author{
SILVA, A. L. S. da, ${ }^{1}$ MORAES-FERNANDES, M. I. ${ }^{2}$ and FERREIRA, A. G. ${ }^{3}$ \\ 'Embrapa Trigo, C.P. 569, CEP 99001-970, Passo Fundo, RS, Brazil \\ ${ }^{2}$ Embrapa Trigo, Passo Fundo, RS, Brazil \\ ${ }^{3}$ Departamento de Botânica, Av. Paulo Gama, 40, CEP 90046-900, Porto Alegre, RS, Brazil \\ Correspondence to: Ana Lúcia Stival da Silva, University of Hamburg, Center for Applied Plant Molecular Biology \\ (AMP II), Ohnhorststrasse, 18, D-22609, Hamburg, Germany, e-mail: Fb8a028@ botanik.botanik.uni-hamburg.de
}

Received October 17, 1997 - Accepted March 10, 1999 - Distributed May 31, 2000

(With 1 figure)

\begin{abstract}
This paper describes a simple procedure for obtention of barley (Hordeum vulgare L.) doubled haploid plants from Brazilian hybrid genotypes. Anatomical and histological examinations showed the reversion of barley pollen to an sporophytic mode of development. A sequence of mitosis led to the formation of multicellular pollen grains. Regeneration of plants occurred either by direct embryogenesis or callus formation followed by differentiation through direct embryogenesis or organogenesis. Plants were formed in the same medium used for induction dispensing an additional regeneration step. This procedure makes doubled haploid production simpler and faster. Plantlets were transferred to another medium for rooting and after that planted in pots with vermiculite and nutrient solution.
\end{abstract}

Key words: anther culture, doubled haploids.

\section{RESUMO}

\section{Método para obtenção de duplo-haplóides de genótipos brasileiros de cevada}

Anteras de cevada (Hordeum vulgare L.) foram cultivadas in vitro, fazendo com que houvesse uma reversão no desenvolvimento dos micrósporos para um modo esporofítico de desenvolvimento. Uma primeira mitose simétrica, seguida de uma sequiência de mitoses, levou à formação de micrósporos multinucleados. A regeneração de plantas ocorreu tanto por embriogênese direta quanto pela formação de calos, com posterior diferenciação via embriogênese indireta ou organogênese. Os embriões e calos androgenéticos mostraram grande potencial para regeneração, e plantas verdes e albinas foram regeneradas no mesmo meio utilizado para indução, sendo a transferência para outro meio necessária somente para dar prosseguimento ao desenvolvimento e ao enraizamento das plântulas. A possibilidade de induzir pró-embrióides e regenerar plantas em um único passo, sem necessidade de transferência para um meio específico de regeneração, aumenta a rapidez e a eficiência da técnica de cultura de anteras.

Palavras-chave: cultura de anteras, duplo-haplóides.

\section{INTRODUCTION}

Androgenesis may be defined as the reversion of pollen grains to an sporophytic mode of development (Maheshwari et al., 1983). When anthers are cultured in vitro, part of the microspores are induced to divide themselves, giving rise to small cell aggregates that turn out into a callus or an embryo. In the case of cereals, it seems that polarity of the first mitotic division plays an important role in this process (Sun, 1981). In general, the sporophytic route is triggered by a symmetrical mitosis, which disturbs the original polarity required to direct normal gametophytical 
development of pollen grains. Depending on the occurrence of spontaneous doubling of chromosomes, haploid or doubled haploid plants may arise after differentiation. Anther culture technique for haploid production has been described in 237 different species belonging to 83 genera and 37 families and successfully applied for the creation of new varieties of cereals and solanaceous species, like rice, barley, wheat, Triticale, tomato, and tobacco (Dunwell, 1985).

The first protocol of barley anther culture was established by Clapham (1973). At that time, frequency of green plant regeneration was very low. During the last twenty years improvements in the composition of culture media caused a change in the pattern of differentiation. Instead of disorganized calluses, there was an induction of embryos, increasing substantially the efficiency of plantlet regeneration (Olsen, 1987; Hunter, 1987; Sorvari \& Schieder, 1987; Finnie et al., 1989; Daniel \& Baumann, 1990; Last \& Bretell, 1990; Orshinsky et al., 1990; Kao et al., 1991; Cai et al., 1992; Scott \& Lyne, 1994a, b). When compared with organogenesis, regeneration via direct embryogenesis has many advantages. According to Reinert \& Bajaj (1977) and Clapham (1977), formation of embryos reduces the proportion of albinism and occurrence of chimerism and chromosomal abnormalities, assuring that doubled haploids produced in vitro will truly reproduce the genetic variability originally present in the population of microspores. Different factors (genotype and culture conditions of donor plants, culture media composition, light and temperature during anther incubation) may influence the route adopted in vitro. This paper describes the process of differentiation from pro-embryoids into whole plants in barley anther culture.

\section{MATERIAL AND METHODS}

Anthers were collected from eleven $\mathrm{F}_{1}$ populations, derived from crosses made at EmbrapaNational Research Center for Wheat (CNPT) $\left(28^{\circ}\right.$ 15' S, 52 $24^{\prime}$ 'W, $687 \mathrm{~m}$ ) (Stival da Silva et al., 1997). Plants were cultivated in pots, with ambient light and temperature during the winter of 1993.

Spikes containing pollen grains at mid-uninucleate stage were harvested every two days, early in the morning. The stage of development of pollen grains was estimated through the distance from the base of the flag-leaf and the anterior leaf. For the tested genotypes and existing environmental conditions, this distance was about $50 \mathrm{~mm}$. Immediately after harvesting, tillers were sterilized in the laminar flow with ethanol $96^{\circ}$. Spikes were removed and stored at $4^{\circ} \mathrm{C}$, in the dark, as described by Huang \& Sunderland (1982).

After ten days of pretreatment in the cold, anthers were removed from the spikes under the stereoscopic microscope and placed in Petri dishes containing basic N6 medium (Chu, 1981), plus vitamins $(100 \mathrm{mg} / \mathrm{L}$ myo-Inositol, $1 \mathrm{mg} / \mathrm{L}$ thiamine, $0.5 \mathrm{mg} / \mathrm{L}$ nicotinic acid, $0.5 \mathrm{mg} / \mathrm{L}$ pyridoxine), aminoacids $(750 \mathrm{mg} / \mathrm{L} \mathrm{L}$-glutamine and $2 \mathrm{mg} / \mathrm{L}$ glycine), growth regulators $(2 \mathrm{mg} / \mathrm{L} \alpha$-naphthaleneacetic acid and $1 \mathrm{mg} / \mathrm{L}$ 6-benzylaminopurine), $60 \mathrm{~g} / \mathrm{L}$ maltose (Merck/Mikrobiologie), $8 \mathrm{~g} / \mathrm{L}$ agarose (Sigma, Type VII, low melting point). Anthers were incubated in the dark, at $25 \pm 1{ }^{\circ} \mathrm{C}$, during 40 days. By the end of this period, androgenetic structures (calluses or embryos) in the surface of the anthers were evident. Petri dishes were then placed in the light $\left(60 \mu \mathrm{E} \mathrm{m}^{-2} \cdot \mathrm{s}^{-1}, 12 \mathrm{~h}\right)$. Germination of embryos occurred in the same medium, in one step, avoiding the need to employ an specific medium for regeneration of green plants. Green plantlets were transferred to test tubes containing modified MS medium (Olsen, 1987), with $30 \mathrm{~g} / \mathrm{L}$ sucrose, $7 \mathrm{~g} / \mathrm{L}$ agar (Difco, Bacto-agar) and $0,5 \mathrm{mg} / \mathrm{L}$ AIA for rooting and further development of leaves.

Plants with abundant roots were planted in pots containing vermiculite and wetted with Hoagland's solution (Hoagland \& Arnon, 1938). Pots were covered with an inverted beaker, which was gradually removed to avoid desiccation. After ten days of hardening plants could be transferred to pots containing a mixture of soil and manure $(2: 1)$ and cultivated in the greenhouse until grain formation. Haploids could be recognized by counting the chromosomes, by their sterility, smaller size and tiny leaves. A high rate of spontaneous doubling was observed, making unnecessary to treat plants with colchicine in order to restore the fertility.

\section{Cytological and histological analysis}

Formation and development of pro-embryoids inside the anthers were monitored every week, during the first month of culture. Contents of the anthers were examined in the microscope after 
crushing and staining with acetic carmine. Androgenetic structures present by the end of the first month of culture were fixed with glacial acetic acid and ethanol (3:1). Preparation of slides followed the procedure described by Johansen (1940). Staining was done with safranine (30 min) and fast green (5 min).

\section{RESULTS AND DISCUSSION}

The sequence of ontogenetic events described in this paper is very similar to the one described for Hordeum spontaneum by Piccirilli \& Arcioni (1991). After the first mitosis (Fig. 1A), in vitro sporophytic development continued through subsequent divisions. Multicellular pollen grains, containing 8 to 12 cells, separated by complete cell walls, were identified after 14 days in culture (Fig. 1B). It is possible to observe that while part of the microspores have adopted the sporophytic route the majority of them have degenerated. According to Hoekstra et al. (1993), only 25\% of the viable, potentially embryogenic microspores effectively divide themselves when cultured in vitro. Not all of these proceed their sporophytic development. According to Dunwell (1985), the production of complete cell walls separating the daughter-cells is fundamental for the formation of normal embryos. Bajaj (1983) describes pollen
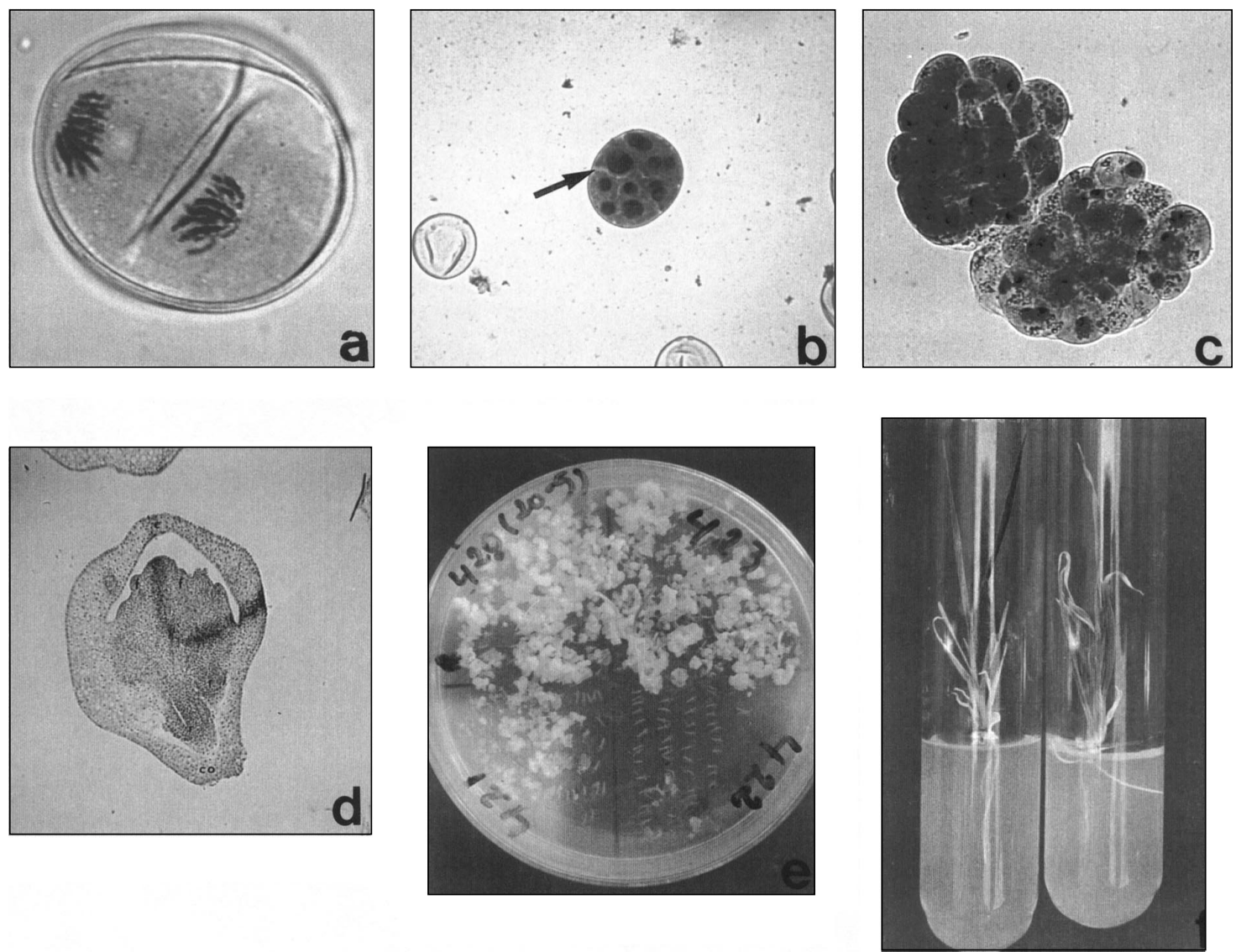

Fig. 1 - (A) First mitotic division of a microspore $(1250 \mathrm{x})$. (B) Multicellular pollen grain, after 12 days in culture, containing 12 cells, separated by cell walls (see arrow) $(200 \mathrm{x})$. (C) Globular pro-embryos liberated from inside the anthers after the rupture of the exine $(200 \mathrm{x})$. (D) Longitudinal cut through an isolated embryo $(100.8 \mathrm{x})$. (E) Petri dish with cultured anthers showing the induction of androgenetic structures which give rise to plantlets (see arrow) in the same culture medium. (F) Green plantlet. 
grains containing up to 30 cenocitic nuclei but these soon degenerate.

The death of some cells may be responsible for the low level of conversion from multicellular structures into complete embryos (Dunwell, 1985). The death of these structures may also be caused by inadequate diffusion of nutrients, by the presence of toxic products released by the anther wall, by chromosomal failures or by the appearance of deleterious recessive genes.

After rupture of the exine globular pro-embryos are setted free (Fig. 1C). These pro-embryos gave rise to isolated embryos. The presence of typical bipolar embryos was confirmed by anatomical cuttings (Fig. 1D). It was possible to identify most of the structures that comprise a normal embryo, like an scutellum, coleoptile, coleorriza, root and apical meristems.

On the other hand, clusters of globular embryos that stacked together, resembling a highly friable callus (embryo-like calluses) were observed. According to Norstog (1979), these clusters are comparable to the protocorm of orchids, since they do not possess a single embryonic axis, but are composed of many different meristematic centers that may differentiate either regular, symmetrical embryos and/or roots and shoots. Embryo-like calluses have been frequently described in barley anther culture (Marsolais \& Kasha, 1985; Kao et al., 1991). Piccirilli \& Arcioni (1991) suggested that their formation may be related to a premature development of cell wall and bursting of the exine, causing a disturb in the polarity of the microspore.

According to Norstog (1979), callusing may be inherent to young and undifferentiated embryos, in which the routes of differentiation are not yet very well-established or, alternatively, a product of media and method deficiencies that do not allow the normal development of immature embryos. Orshinsky et al. (1990) showed that during the initial period of induction in wheat individual embryos predominated but after staying for a long time in the same hormonal balance these embryos adopted a disorganized pattern of cell proliferation that ends by originating small and compact aggregates. In order to prevent this circumstance, anthers should be cultured in liquid media where the appropriate hormonal and mineral balance can be maintained by continuously replenishment.
Plantlets were regenerated in the same medium used for induction of androgenesis and transfer was necessary just for rooting (Figs. 1E and F). Orshinsky et al. (1990) described the same conditions for wheat anther culture. The possibility to induce pro-embryos and regenerate plantlets in one step increases the efficiency and makes anther culture faster and simpler to execute. As described in a previous paper (Stival da Silva et al., 1997) this method has been used to produce an average of 3,5 green plants/100 plated anthers. According to Foroughi-Wehr \& Friedt (1984) and Kühlmann \& Foroughi-Wehr (1989) this rate of doubled haploid production enables the technique to be applied in barley breeding programs.

Acknowledgments - The experiments were carried out at EMBRAPA - National Research Center for Wheat (CNPT) and the authors are grateful to the direction of this institution for providing material and human resources. We are specially thankful to Gelsi Galon for his valuable technical assistance. Thanks are also due to Dr. Jorge Ernesto Mariath, from the Universidade Federal do Rio Grande do Sul, Department of Botany, for helping on the preparation of slides and histological analysis. This work received financial support from FINEP and FAPERGS. A.L.S. da Silva was the recipient of a Master's fellowship from CNPq.

\section{REFERENCES}

BAJAJ, Y. P. S., 1983, In vitro production of haploids. In: W. R. Sharp, P. V. Ammirato \& Y. Yamada (eds.), Handbook of plant cell culture: techniques for propagation and breeding. MacMillan Publishing Company, New York, pp. 228-287.

CAI, Q., SZAREJKO, I., POLOK, K. \& MALUSZYNSKI, M., 1992, The effect of sugars and growth regulators on embryoid formation and plant regeneration from barley anther culture. Plant Breeding, 109: 218-226.

CHU, C. -C., 1981, The $\mathrm{N}_{6}$ medium and its applications to anther culture of cereal crops. In: Symposium on Plant Tissue Culture, Peking, 1978. Proceedings. Pitman Advanced Publishing Program, Boston, pp. 43-50.

CLAPHAM, D., 1973, Haploid Hordeum plants from anthers in vitro. Zeitschrift Pflanzenzuechtung, 69: 142-155.

CLAPHAM, D. H., 1977, Haploid induction in cereals. In: J. Reinert \& Y. P. S. Bajaj (eds.), Applied and fundamental aspects of plant cell, tissue and organ culture. Springer Verlag, Berlin, pp. 279-298.

DANIEL, G. \& BAUMANN, A., 1990, Einfluss verschiedener Faktoren auf die Pflanzen-regeneration in der Antherenkultur bei Sommer- und Wintergerste. Landwirtschaftliches Jahrbuch, 67: 609-617. 
DUNWELL, J. M., 1985, Embryogenesis from pollen in vitro. In: M. Zaitlin, P. Day \& A. Hollaender (eds.), Biotechnology in plant science: relevance to agriculture in the eighties. Academic Press, Orlando, pp. 49-76.

FINNIE, S. J., POWELL, W. \& DYER, A. F., 1989, The effect of carbohydrate composition and concentration on anther culture response in barley (Hordeum vulgare L.). Plant Breeding, 103: 110-118.

FOROUGHI-WEHR, B. \& FRIEDT, W., 1984, Rapid production of recombinant barley yellow mosaic virus resistant Hordeum vulgare lines by anther culture. Theoretical and Applied Genetics, 67: 377-382.

HOAGLAND, D. R. \& ARNON, D. I., 1938, The waterculture method for growing plants without soil. University of California, Berkeley, 39p. (Circular, 347).

HOEKSTRA, S., VAN ZIJDERVELD, M. H., HEIDEKAMP, F. \& VAN DER MARK, F., 1993, Microspore culture of Hordeum vulgare L.: the influence of density and osmolality. Plant Cell Reports, 12: 661-665.

HUANG, B. \& SUNDERLAND, N., 1982, Temperature-stress pretreatment in barley anther culture. Annals of Botany, 49: 77-88.

HUNTER, C. P., 1987, Sittingbourne, Kent. Plant generation method. Int. Cl. ${ }^{4}$ A01G 7/00. GB 0245898 A2. 22 abr. 1987; 19 nov. European Patent Application.

JOHANSEN, D. A., 1940, Plant microtechnique. McGrawHill, New York, 523p.

KAO, K. N., SALEEM, M., ABRAMS, S., PEDRAS, M., HORN, D. \& MALLARD, C., 1991, Culture conditions for induction of green plants from barley microspores by anther culture methods. Plant Cell Reports, 9: 595-601.

KÜHLMANN, U. \& FOROUGHI-WEHR, B., 1989, Production of doubled haploid lines in frequencies sufficient for barley breeding programs. Plant Cell Reports, 8: 78-81.

LAST, D. I. \& BRETTELL, R. I. S., 1990, Embryo yield in wheat anther culture is influenced by the choice of sugar in the culture medium. Plant Cell Reports, 9: 14-16.

MAHESHWARI, S. C., RASHID, A. \& TYAGI, A. K., 1983, Anther/pollen culture for production of haploids and their utility. International Association for Plant Tissue Culture Newsletter, 41: 2-9.

MARSOLAIS, A. A. \& KASHA, K. J., 1985, Callus induction from barley microspores. The role of sucrose and auxin in a barley anther culture medium. Canadian Journal of Botany, 63: 2209-2212.
NORSTOG, K., 1979, Embryo culture as a tool in the study of comparative and developmental morphology. In: W. R. Sharp, P. O. Larsen, E. F. Paddock \& V. Raghavan (eds.), Plant cell and tissue culture: principles and applications. Ohio State University Press, Columbus, pp. 179-202.

OLSEN, F. L., 1987, Induction of microspore embryogenesis in cultured anthers of Hordeum vulgare: the effects of ammonium nitrate, glutamine and asparagine as nitrogen sources. Carlsberg Research Communications, 52: 393-404.

ORSHINSKY, B. R., MCGREGOR, L. J., JOHNSON, G. I. E., HUEL, P. \& KARTHA, K. K., 1990, Improved embryoid induction and green shoot regeneration from wheat anthers cultured in medium with maltose. Plant Cell Reports, 9: 365-369.

PICCIRILLI, M. \& ARCIONI, S., 1991, Haploid plants regenerated via anther culture in wild barley (Hordeum spontaneum C. Kock). Plant Cell Reports, 10: 273-276.

REINERT, J. \& BAJAJ, Y. P. S., 1977, Anther culture: haploid production and its significance. In: J. Reinert \& Y. P. S. Bajaj (eds.), Applied and fundamental aspects of plant, cell, tissue and organ culture. Springer-Verlag, Berlin, pp. 251-267.

SCOTT, P. \& LYNE, R. L., 1994a, The effect of different carbohydrate sources upon the initiation of embryogenesis from barley microspores. Plant Cell, Tissue and Organ Culture, 36: 129-133.

SCOTT, P. \& LYNE, R. L., 1994b, Initiation of embryogenesis from cultured barley microspores: a further investigation into the toxic effects of sucrose and glucose. Plant Cell, Tissue and Organ Culture, 37: 61-65.

SORVARI, S. \& SCHIEDER, O., 1987, Influence of sucrose and melibiose on barley anther cultures in starch media. Plant Breeding, 99: 164-171.

SILVA, A. L. S. da, FERNANDES, M. I. B. de M., ARIAS, G., FERREIRA, A. G. \& HAAS, J. C., 1997, Production of androgenetic barley doubled haploid lines. Pesquisa Agropecuária Brasileira, 32: 1159-1166.

SUN, C. -S., 1981, Androgenesis in cereal crops. In: Symposium on Plant Tissue Culture, Peking, 1978. Proceedings. Pitman Advanced Publishing Program, Boston, pp. 117-123. 